\title{
Rereading a Classic Book for Young Adults: The Representation of Death in Aidan Chambers' Dance on My Grave
}

\author{
Dimitrios Politis \\ Department of Educational Sciences and Early Childhood Education, University of Patras, Patras, Greece \\ Email: dimpolitis@upatras.gr
}

How to cite this paper: Politis, D. (2021). Rereading a Classic Book for Young Adults: The Representation of Death in Aidan Chambers' Dance on My Grave. Advances in Literary Study, 9, 1-10. https://doi.org/10.4236/als.2021.91001

Received: December 10, 2020

Accepted: January 5, 2021

Published: January 8, 2021

Copyright $\odot 2021$ by author(s) and Scientific Research Publishing Inc. This work is licensed under the Creative Commons Attribution International License (CC BY 4.0).

http://creativecommons.org/licenses/by/4.0/

\section{(c) (i) Open Access}

\begin{abstract}
Although in 1982 Chambers' book, Dance on My Grave, was considered bold, rather provocative, today, almost forty years later we can only treat it as one of the classic daring books that still attracts and challenges modern readers, teenagers and adults. And if the issue of homosexuality mainly identifies the novel nowadays seems commonplace, the matter of death stands virtually as a threatening scene throughout this book. However, the novel's central hero named Hal Robinson, trying to clear his memories up, after he had experienced an adolescent love that still surpasses everything, entices all but poetically his teenage friends-readers into a dance that exorcizes death and praises life. Following Hal in his pursuits, the present paper seeks, though not exhaustively, to provide some more insights into Chambers' novel concerning the torturous search of the self as well as the depressing idea of inevitable death that is very closely linked to the transgressions of adolescence.
\end{abstract}

\section{Keywords}

Adolescence, Aidan Chambers, Death, Identity, Homosexuality, YA Readers

\section{Introduction}

In Dance on My Grave ${ }^{1}$ we are introduced to death manifested both literally and

${ }^{1}$ One of the most read books written by Chambers and second in the Aidan Chambers' "Dance Sequence" (of six novels: Breaktime, Dance on My Grave, Now I Know, The Toll Bridge, Postcards from No Man's Land and This Is All: The Pillow Book of Cordelia Kenn), Dance on My Grave was first published in 1982. The book has been edited out several times to date, while it has been translated into many languages. In 2020 it also formed the basis of the film Summer of 85 (Été 85) directed by French François Ozon. However, obviously due to its theme, the novel "was challenged at the Montgomery County Memorial Library System in 2004 by the Library Patrons of Texas" https://en.wikipedia.org/wiki/Dance on My Grave\#cite ref-9 accessed on 05/12/2020). 
metaphorically. The title of the book is itself both challenging and startling, since we associate inescapably dancing with celebration. Death conversely is something to be dealt with, an unpleasant reminder of our mortality, we package off our loved ones in a sorrowful ritual, a funeral dirge. Certainly, the English tradition of death is a somber, sorrowful affair. Dancing would be considered at best inappropriate, more likely as offensive, and disrespectful.

Through reading the book we are forced to confront the issue of death ${ }^{2}$ on many different levels. Literally through Barry Gorman's death, subjectively through Hal's preoccupation with "death itself" and also metaphorically through the death of self in the characters themselves. Hal examines the idea of death of self in his description of the process of writing. "Making this Book of bits. This mosaic of a me-that-was. This memorial to two dead people." (Chambers, 1982: p. 5) Throughout the book adolescence is presented as an inherently unstable state and as a peculiar world which is "unable to participate fully in the broader adult and familial world" (Browne, 2020: pp. 5-7), a "period of carnival when the normal rules of human behavior [...] are suspended" (Kokkola, 2013: p. 2), a dialectic but torturous and disastrous process between identity, sexuality, and death (Trites, 2000: p. 122).

\section{Following Hal into His Memories, or When Death Becomes a Painful Obsession}

The novel is about a short love affair between two boys, Hal and Barry, in a seaside town in southern England. The idyll ends when the two teenagers fight over a girl Barry has spent the night with, and Barry rushes off on his motorcycle to a fatal crash. The book sets out all the details and facts of this relationship through Hal's memories and reflections.

The story opens with a news report, relating an event which has wounded the public sense of decency. A boy, who we find later to be Hal, has been arrested after performing "strange antics on the deceased boy's grave". The "antics" transpire to be a dance more commonly viewed as being a celebration of life, but at the same time a desire to avoid confronting the issue or idea of death as well as the fear of the unknown, the untenability that creates this fear of facing up to death.

Hal, a sixteen year old boy, is the main protagonist in the story. He represents the "dominant voice" of a first-person young narrator, "angry and rueful, articulate and witty, full of quotations and word-play, self-conscious, self-obsessed, sex-obsessed, explicit and vivid, full of the facetiousness and stylistic fireworks of intelligent adolescence" (Meek \& Watson, 2003: p. 37). His lack of self-confidence is manifested in his preoccupation with self and in his morbid fascination, his neurosis about death. Death is his hobby, not dead bodies, but death itself. Hal relates how he "caught" his interest in death as a disease, he relates the events of the book as a kind of exorcism. Interestingly, it is the act of re-telling his expe-

\footnotetext{
${ }^{2}$ The idea of death continues to occupy human beings of all time and ages. A very helpful as well as a great resource for further reading concerning the issue of death and its multiple parameters is The Oxford Book of Death edited by Dennis Joseph Enright (Oxford University Press, 1987).
} 
riences that he feels changes him, not the experiences themselves. As he confesses, "Because of writing the story, I am no longer now what I was when it all happened. Writing this story is what has changed me; not having lived through the story" (Chambers, 1982: p. 221).

As William Banks (2009: p. 35) asserts, many characters and especially the queer ones, in young adult novels, "are most useful if they're dead or gone". Katelyn Browne (2020: p. 1) observes that all these characters "have been closely connected with death", while Roberta Seelinger Trites (2000: p. 122) affirms that engaging with death seems inevitable. Actually, the whole of Chambers' book is consumed by death. The language and symbolism are throughout echo mortality. Hal describes the people on the beach "[...] a morgue of sweating bodies laid out on slabs of towels" (Chambers, 1982: p. 9), and Barry, at their first meeting, as "The Body" (Chambers, 1982: p. 22). Hal commentates his own and the actions and objects around him in terms of death. The bath at Mrs Gorman's house he sees as a tomb, a sarcophagus. He also contemplates the Egyptians faith in death through the building of the pyramids and later relates old, cultural traditions of treating dead people, traditions which seem repulsive and barbaric (Chambers, 1982: p. 200).

Hal's interest in death is more than adolescent preoccupation; it is natural for someone at the brink of adult life, experiencing for the first time the joy of autonomy, of youth and beauty to be alarmed by the transience of this freedom. Mortality is frightening as age appears to be devoid of possibility. Hal himself views it as a ridiculous, sorrowful state. "My eyes will be palely vacant, staring with gaga incomprehension at all and nothing while weeping from no other sorrow than the blight of age. I will not be able to control my water; will spill my food down my chest where it will leave festering fungoid spots on my holey cardigan, and children will laugh at me in the street and call me unhappy names" (Chambers, 1982: p. 102). Hal defines his own death fascination as lunatic, "if your hobby is death, you must be mad".

Hal's interest in death whilst all-consuming is more academic than fatalistic. Although he does contemplate suicide after Barry's death, Hal is predominantly concerned with staying alive evinced by his reaction to the capsize of the "Tumble", "I was not yet tired enough of life, I decided to wish for a trip to that certain grave. Death I was interested in; being dead, I was not" (Chambers, 1982: p. 17). Hal, however, courts death. In his obsessive search for a bosom friend, he meets Harvey, a mad scientist with a precocious interest in experimenting with electricity. Harvey seems intent on blowing himself up.

Barry, the next contender for the boy with the can of magic beans, also has a death wish - a wish that is realized whilst he is trying to reach the unattainable speed just ahead. The drunk Barry and Hal stumble upon on their way back from the cinema, is also intent on "shuffling off this mortal coil", ${ }^{3}$ trying to dive

\footnotetext{
${ }^{3}$ The phrase refers to the widely known and quoted "To be, or not to be", the opening line of Prince Hamlet's soliloquy/confession in William Shakespeare's Hamlet (Act 3, Scene 1). There are many illusions to Hamlet "shuffling off this mortal coil" in the book. Hal is in many ways Hamlet's foil, haunted by an oath to a dead man to carry out a deed he is reluctant to fulfil. The grappling with the corpse in the morgue echoes Hamlets grappling with Ophelia in her grave. Barry and Hal visit a production of Hamlet in London, afterwards Barry demands that Hal swears to dance on his grave, if he should die first. This is paralleled by the ghost of Hamlets father's demand that Hamlet give an oath of vengeance.
} 
into passing cars. In this particular scene Hal likens their actions to those of corpse thieves trying to get the drunk to safety under the pier. Even Hal's English teacher and mentor $\mathrm{Oz}$ has a reputation for "eat(ing) new boys for breakfast".

We learn through Hal's composition entitled "Time Slip" something of his death fascination. It is a fiction about a thirteen year old's visit to a family graveyard where he is suddenly struck with the realization of his own mortality and of the continuance of time outside of his own existence. He examines the idea of death. What is it? "Every one of these people must have been alive and must have felt like me once. They were inside themselves, like I am inside myself now, looking out of themselves... But then one day they weren't inside themselves anymore. They were dead... Is that what dead means? Not being in your body? (Chambers, 1982: pp. 59-60).

This concern with the nature of death arises throughout the book as an inevitable but redemptive destination (Browne, 2020: pp. 3-4). Hal doesn't view death in any conventional religious sense. Indeed, he is dismissive of religious tradition. Death he sees as the ultimate negation. It is life which confers personal identity. In the farcical scene in the morgue Hal wishes for the corpse in front of him to become Barry again. Failing this he desires to join death, to be in union with Barry, forever in death. "To battle death in death. Enter that eternity with him. Become by not being. Join in forever" (Chambers, 1982: p. 219). Death for Hal is "the truth in negative", it is existence without identity, and it is not being alive!

Hal and Barry have a caustic row over Kari. A mirror is shattered, as are Hal's illusions about his relationship with Barry. Hal runs out of the shop. "Fifty minutes later he was dead... An eyewitness said 'It was like he was trying to fly. Just took off. Unbelievable. Maybe he was drunk or stoned or something. Or just plain crazy"' (Chambers, 1982: p. 180).

The actual death itself is not dramatized. We do not witness the event and the facts are related through $\mathrm{Hal}$ and Mrs Gorman. Much of this is surmise and the event is heavily subscribed with guilt and culpability. Barry's death is unheroic as he dies after crashing his motorbike. His death is not a grand statement, it is arbitrary, meaningless, and it is the tragedy of the everyday and poignant in that respect only. What actually is explored in the book is the effect of the death upon the other characters.

\section{Death as a Point of Departure, or Searching for the Self}

Barry's death is a vehicle for Hal's self-realization. It is through Barry's death that $\mathrm{Hal}$ examines himself, his values and actions. It is the act of writing about the feeling and experiences he felt in the 49 days he shared with Barry that Hal arrives at some essential truths about himself and about life. In this Chambers relies on Hal's reading of Kurt Vonnegut, the idea that essentially "We are what we pretend to be, so we must be careful what we pretend to be". ${ }^{4}$ Hal extends this idea to embrace the notion that we project onto bodies the characteristics

${ }^{4}$ Vonnegut's reflection serves as a motto in the first chapter of the book (Chambers, 1982: p. 8). 
and personalities we desire to find there. This is not a new idea, the cliché "you see what you want to see" is common enough. Nevertheless, it has like most clichés lost much of its potency through excessive use. What Chamber's succeeds in doing is exploring this idea through $\mathrm{Hal}$ in a manner that re-energizes the cliché. We are struck with the appalling nature of identity that we create the "identities" of people around us by casting people in the roles and characters we desire to see in the world that we create for ourselves. In the process of learning part of Hal also, dies, his innocence and idealism. His desire to find the boy with the can of magic beans. At the close of the book, Hal is content to be with Spike as Spike, his search for a bosom friend, a Johnathan, is over. ${ }^{5}$

Hal's epiphany, is in his realization that the world he creates and the characters he peoples that world with are not essentially real. It is a realization achieved through writing about the death of his friend Barry. "I'm harder now. I think. I hope. Maybe I am also more tolerant of a friend being what he is and not what I want him to be" (Chambers, 1982: p. 114).

As Margaret Meek \& Victor Watson (2003: p. 37) assert, Chambers' novels, specifically those of "Dance series", "provide shifting perspectives upon young adult anxiety and obsession". Hal's immediate reaction to Barry's death is one of pained disbelief. This quickly metamorphoses into guilt, catalyzed by Mrs Gorman's accusation "My son is dead... and you killed him". Hal's world is turned upside down. His recriminations, unexpressed anger and frustration manifest in a physical breakdown. He is unable to communicate to his parents the enormity of his grief, without explaining the truth of his relationship with Barry. His collapse is effected by his inability to express his feeling, his remorse, well-illustrated in his interview with his father.

- "Barry Gorman's dead.

...After a while he said, taking it a bit hard aren't you? I mean you haven't known him that long.

-Seven weeks".

-Aye well, things like this happen. You can't let them get you down"

(Chambers, 1982: p. 186).

Hal is isolated by his guilt. Spurned by his disbelief he races to the shop to see if Barry is there. He finds everything neat, with no evidence of the quarrel and pacifies himself with the idea that it was a nightmare. But facing the broken mirrors empty frame he realizes that it is true. Hal is also struck with the realization that he is alone, without identity, no reflection looks back from the shattered mirror, he too in a sense, has ceased to exist.

Chambers explores the nature of personal identity throughout the book, via the sexual and social instability of his protagonists, through their destabilizing experiences (Trites, 2000: p. 54), as they try unconsciously or consciously to ${ }^{5}$ The Biblical reference from I Samuel (18) is vital in understanding Hal's need for the "boy with the can of magic beans" his obsession. David and Johnathan found their love "passing the love of woman", whilst Hal's stumbling upon this reference fuels his persistence to find a Johnathan. 
comply with "normality" (James, 2009: p. 27). Nevertheless, during this process where there is interest even in the female presence, adolescents heroes failure "to assert their agency and thus fulfill the desire to create an identity"' (James, 2009: p. 65). It is worth noting here that Chambers, through the characters of Hal and Barry, challenges the stereotyped homosexual. Both characters are masculine, intelligent, attractive and physical. Thus, the search for the self comes to intensify an adolescent identity crisis (James, 2009: p. 127) and, finally, makes the adolescent protagonists/readers to accept their own mortality (Trites, 2000: p. 119).

Symbolically, Hal changes after the capsize of the "Tumble", Barry gives him new clothes to wear, a new identity. Later Barry buys Hal clothes to wear, clothes that Hal feels uncomfortable in but wears to please Barry. After Barry's death, once $\mathrm{Hal}$ has established and re-evaluated what went on during those 49 days, he burns the clothes in an incinerator, he tries to purge himself of his borrowed persona, and tries to retrieve his own self. Hal and Barry verbally assault one another after Barry's encounter with Kari. Ugly truths are laid bare. Hal describes it as "the saddest moment of all". The shattering of the mirror by Hal is also symbolic of the shattering of his assumed self, the cessation of the fantasy, the crashing re-emergence of reality. "For a sharp split second I say my own face snarling back at me before the pearly brickbat shattered the glass and my fact fell in splinters on the floor" (Chambers, 1982: p. 180).

Hal re-examined the time he spent with Barry, while, wiser through reflection, he realizes that things were not as he thought. It is a humbling painful awakening of consciousness to the truth that his understanding of their relationship was based upon his desire for what that relationship should be, should mean. He defines his relationship with Barry in terms of his obsession for a bosom friend. Hal is blinded into seeing only a creature of his own desire, his own need. It is only after Barry's death that Hal faces up to the cruel realization that things were not as they seemed, that Barry was not in reality "the boy with the can of magic beans". "But at the time... There was only one imperative: the two of us together. I thought” (Chambers, 1982: p. 162).

It is not essentially Barry's death that makes Hal so ill, but the retelling of the experience. The events of the book are a symbolic journey of learning for Hal. At the end of the journey $\mathrm{Hal}$ is wiser, more sober and in some ways more ordinary than the idealist he was. Hal has undertaken the exposition of himself (thorough writing) as a justification for his inexplicable behavior to the adult authority that demands an explanation. Hal is coerced into a painful dissection of himself, his motives and actions. He distances himself from his actions by writing in the third person. And through writing about his actions, faces up to his obsession. The theme of the book is Hal's obsession, Barry's death is merely a vehicle for this examination, the events through which Hal faces up to his own driving forces.

The physical manifestations of sickness that Hal experiences are indicative of the painful awakening of consciousness that he is experiencing. Hal himself describes it as "a volcanic eruption of misery" (Chambers, 1982: p. 168). His misery 
is understandable, he has been left alone to face up to himself. Barry has betrayed his idea of friendship by precipitating this unwelcomed self-examination. "My mother calls it a migraine. Maybe it is. But I know what I call it. Fright. Funk. Shame. Guilt. Locked up anger trying to get out. Self-pity" (Chambers, 1982: p. 167).

Chambers uses Hal's visit to the morgue to examine the nature of identity, the disparity between what is and what seems to be. Hal dressed in the guise of a lovesick girl, visits the morgue, requiring concrete proof that his lover is dead. It is only because Hal reacts inappropriately to the sight of Barry's body that the travesty is realized, the scene moves from melodrama to farce as Hal's disguise is literally stripped away to the astonishment of the morgue attendant. This symbolic uncovering is a major theme in the book. We witness it after the capsize of the "Tumble" when Hal is forcibly stripped by Mrs. Gorman and later when Hal visits Barry's grave and literally attempts to uncover the body by attacking the grave in a frenzy of grief. Chamber's interest lies in the layers individuals apply to distort truth, or to create a more palatable reality for themselves.

$\mathrm{Hal}$ is disturbed by his transformation and only goes through with the scenarios because of his compulsion to see Barry once more. "I've got this compulsion. It's crazy, I know. But I've got to see him. I mean his body. I have to know for certain. I can't explain. I just have to, that all” (Chambers, 1982: p. 198). Hal feels that he is surrendering his identity through his disguise. He feels vulnerable and exposed. His ensuing de-frocking at the hands of the morgue attendant echoes Kurt Vonnegut. "We are what we pretend to be, so we must be careful what we pretend to be". This warning of the peril of failing to be vigilant is dramatically enacted in the morgue, Hal lets his guard slip and his identity is laid bare for all to see.

$\mathrm{Hal}$ is determined to carry out his oath to dance on his grave. For Hal this action is necessary to appease his guilt, to acknowledge his friendship that was and to affirm his new realized self, his aloneness. Hal feels that his sickness is attributed to his failure to perform the dance. “I'm stuck with this till I've kept my promise" (Chambers, 1982: p. 229). This haunting of an oath unfulfilled strongly echoes Hamlet again. "I promised Barry, I said, to dance on his grave. He would have danced on mine if I had died first, it was an oath" (Chambers, 1982: p. 225).

In essence Hal's dance is a ritualistic casting off of Barry, a recognition of what was, a releasing, a letting go. It is during the first dance that Hal acknowledges his anger and grief, letting himself cry. Hal's anger manifests in his hacking at Barry's grave. He is angry at being left alone, to confront reality alone. "Being angry as well as sad, but not knowing why I was angry, made me even more upset. I started gasping for breath as the tears choked me...And in a frenzy began hacking, stabbing, digging, using his lollipop number-stake as a spade, flinging the soil aside in any direction" (Chambers, 1982: p. 235).

The violence of the dance is suggestive of the dramatic change that Hal has undergone. He fulfils his oath through the dance but also more importantly he mourns the death of his own self, his innocence, idealism and obsession. 'I had 
put to death and was being put to death. But there is no way of telling about the tissue of death of my own self, or about the gangrene rotting away my dreams of bosom palship" (Chambers, 1982: p. 191).

Hal manages to communicate to us an idea of how he is feeling as he journeys through the events of the book. We are given an insight into his experiences, his frustrations and pain. Hal employs an elevated vocabulary and is unashamed of stating frankly how he feels. In the process of writing about his experiences Hal continually comes across the limitation of language and through this his inability to describe accurately or appropriately his experiences and feeling. The impossibility Hal feels of conveying accurately his experiences into words, serves to heighten the effect of what he does describe. We feel that what is stated about his pain and anguish has failed to convey the intensity of the experience, due to the practical constraints of the language.

The elusivity of language and meaning are closely mirrored by our understanding of death. Outside of religious tradition it remains an enigma. Through the events of the book it appears senseless and arbitrary. Chambers does not strive to make death more acceptable or meaningful. Whilst characters in the book do hold religious beliefs, Chambers does not try to justify death as part of a divine process a moving on to eternal life. It is the effect of death upon the living that is explored. Chambers does not avoid examining the negative effect of death, the painful loss, the hideous banality of it. All this is explored through Hal. The novel is about the living and the effect of a characters death upon their lives. Hal's final dance is symbolic of his recognition of what had been and has passed, it is also a celebration of his own life.

Chambers uses the theme of death to examine our human condition as John M Manners writes, "The attitude of men to the death of their fellows is of unique significance for an understanding of our human condition... The knowledge that we must die gives us our perspective for living, our determination to live in such a fashion that we transcend our tragic limitation" (quoted in Enright, 1983: p. 8). Hal certainly is clearer about his own self and his own life after the events of the book. Barry's death is the catalyst for his examination of his life, his values and needs. Indeed it is impossible in many ways for this to be otherwise. It is life that helps us to form our thoughts about death and serves as a metaphor for death. We are unable to talk about death without (also) talking about life. As death is unknown, unexperienced, we must talk about the experienced, about life if we are to speak convincingly and interestingly about death. It is through Hal's examination of his life and feelings that we begin to understand Barry's death. It is from the hurt experienced by an adolescent muddled boy that we grasp an idea of what death is.

Many of the characters in the book die a kind of death, whereas change is viewed as a kind of dying. The figure of Hal's mother is that of a pathetic shadow of a former confident woman. She is meek, self-effacing, defined by her status as a wife and mother, obsessed with cleanliness and with not upsetting her hus- 
band. The ghostly woman has also died, her personal death of self is more disturbing because she still exists, although spiritless. "If I think of her when I am on my own, she's like she was when I was little; laughing, busy, always on the go, and talking all the time. But she isn't like that now. Now she is a frightened woman who hides [....]" (Chambers, 1982: p. 231). We witness her hiding from a violent film on the television behind her book entitled Mrs. Pinkerton Came to Die. In her exchanges with her son she is without opinion, indecisive, almost without will. She presents a sad figure of a human being hiding from the world, frightened of life.

\section{As an Epilogue}

Rereading Chambers' novel in this paper, I actually decided to reflect own reading, a past reading many years ago. Furthermore, of the many theoretical texts that have dealt with YA Literature in the meantime-e.g. regarding the various conceptualizations and research methodologies of adolescence (Trites, 2014; Gavin, 2012), or the new directions in the study of Children's and YA Literature (Wolf, Coats, Enciso \& Jenkins, 2011; Reynolds, 2007; Hunt, 2004; McCallum, 1999)—some have led me to enrich my present approach with a certain amount of additional insights detected throughout Chambers' novel.

Among the three preponderant discourses Roberta Seelinger Trites (2000: p. 122) distinguishes in YA novels-that is to say: identity, sexuality, and death-the latter seems to be the most powerful in Dance on My Grave, as it essentially includes and unites the other two. As a result, the ongoing association between the three does not surprise us at all as readers, while death through the search for identity and sexuality appears almost expected. Besides, Chambers extends the idea of death from the literal to the metaphoric.

Chambers employs a controversial and sensitive theme in choosing to examine death in his book. Faithful to his point of view that literature for non-adult readers "at its best attempts to [...] recreate and seek for meanings in human experience" Chambers (2000: p. 42), he really explores areas of human experience that are ugly and unpleasant, areas we would perhaps rather not dwell upon, in order to elucidate them, to re-interpret the old sense of things (Rosenblatt, 1978: pp. 12-13, 107-108). Through Hal we witness a struggle with obsession, possessiveness, jealously and death. Hal wrestles with despair and with the problems of identity, reality and truth. The author through his protagonist challenges our acceptance of traditional customs, encouraging us to question whether Hal's dance is essentially offensive or simply another type of ritual. Hal's ritualistic dance is viewed as a horrible desecration, a sacrilegious abomination because it is not commonplace or accepted behavior. Objectively, it is no more absurd than accepted rituals of death.

Aidan Chambers in Dance on My Grave, albeit through death, triumphs in challenging traditional gender definitions whilst presenting the reader with a powerfully well written book. After reading the novel we are not left with any 
marvelous formula that will address the issues raised. What is achieved is a raising of our consciousness, an opportunity for the reader to dwell upon these areas for themselves. In fact, every literary narration/incident, even that of death, as "an event in time" in Rosenblatt (1978: p. 12) words, affects us not only when we come together with the literary text but also after reading it, later, during our real life as human beings.

\section{Conflicts of Interest}

The author declares no conflicts of interest regarding the publication of this paper.

\section{References}

Banks, W. P. (2009). Literacy, Sexuality, and the Value(s) of Queer Young Adult Literatures. English Journal, 98, 33-36. http://www.jstor.org/stable/40503258

Browne, K. R. (2020). Reimagining Queer Death in Young Adult Fiction. Research on Diversity in Youth Literature, 2, Article 3. https://sophia.stkate.edu/rdyl/vol2/iss2/3

Chambers, A. (1982). Dance on My Grave. London, Sydney and Toronto: The Bodley Head.

Chambers, A. (2000). Booktalk: Occasional Writing on Literature and Children (3rd ed.). South Woodchester: The Thimble Press.

Enright, D. J. (1983). The Oxford Book of Death. Oxford, New York: Oxford University Press.

Gavin, A. (2012). Robert Cormier: A New Casebook. Basingstoke-Hampshire, New York: Palgrave MacMillan. https://doi.org/10.1007/978-1-137-28488-4

Hunt, P. (2004). International Companion Encyclopedia of Children's Literature (Vol. I \& II). New York, London: Routledge. https://doi.org/10.4324/9780203325667

James, K. (2009). Death, Gender, and Sexuality in Contemporary Adolescent Literature. London: Routledge. https://doi.org/10.4324/9780203885154

Kokkola, L. (2013). Fictions of Adolescent Carnality: Sexy Sinners and Delinquent Deviants. Amsterdam, Philadelphia, PA: John Benjamins. https://doi.org/10.1075/clcc.1

McCallum, R. (1999). Ideologies of Identity in Adolescent Fiction: The Dialogic Construction of Subjectivity. New York, London: Routledge.

Meek, M. S., \& Watson, V. (2003). Coming of Age in Children's Literature: Growth and Maturity in the Work of Philippa Pearce, Cynthia Voigt and Jan Mark. London, New York: Continuum.

Reynolds, K. (2007). Radical Children's Literature: Future Visions and Aesthetic Transformations in Juvenile Fiction. Basingstoke-Hampshire, New York: Palgrave Macmillan. https://doi.org/10.1057/9780230206205

Rosenblatt, L. M. (1978). The Reader, the Text, the Poem: The Transactional Theory of the Literary Work. Carbondale, IL: Southern Illinois University Press.

Trites, R. S. (2000). Disturbing the Universe: Power and Repression in Adolescent Literature. Iowa City, IA: Iowa University Press.

Trites, R. S. (2014). Literary Conceptualizations of Growth: Metaphors and Cognition in Adolescent Literature. Amsterdam, Philadelphia, PA: John Benjamins. https://doi.org/10.1075/clcc.2

Wolf, S. A., Coats, K., Enciso, P. A., \& Jenkins, C. A. (2011). Handbook of Research on Children's and Young Adult Literature. New York, London: Routledge. https://doi.org/10.4324/9780203843543 